\title{
Desalination and Defluoridation of Tap Water by Electrodialysis
}

\author{
Soumaya Gmar ${ }^{1}$ - Ilhem Ben Salah Sayadi ${ }^{1}$. \\ Nawel Helali ${ }^{1}$ - Mohamed Tlili $^{1} \cdot$ Mohamed Ben Amor $^{1}$
}

Received: 28 February 2015 / Accepted: 1 September 2015 / Published online: 13 October 2015

(C) Springer International Publishing Switzerland 2015

\begin{abstract}
The water resources in Tunisia are very limited and not fairly distributed: $80 \%$ of them are located in the north and only $20 \%$ in the south. In addition, $50 \%$ of them are characterized by a bad quality since they have salinity greater than $1.5 \mathrm{~g} \mathrm{~L}^{-1}$. The bad quality is not only due to the high salinity, but also to the presence of natural pollutants such as fluoride. In fact, according to physicochemical analyses of samples of tap waters collected by the Regional Service of Environmental Health from different monitoring sites in mining area (south of Tunisia), in February 2014, it was shown that waters were contaminated by fluoride and contained high concentrations of sulphate and chloride anions. Fluoride concentrations varied between 0.8 and $4 \mathrm{mg} \mathrm{L}^{-1}$, and then, greatly exceeded the World Health Organization (WHO) standards in some monitoring sites. In this study, the electrodialysis (ED) technique was applied to remove fluoride from these waters. Experiments were carried out using a pilot unit as a conventional ED in batch recirculation mode. It was shown that ED is an efficient technique to remove fluoride and to reduce salinity of water. Removal rate of fluoride tended to $92 \%$ and the concentrations of different species in the treated water were below the amounts recommended by WHO for drinking water. Considering the effect of chloride and sulphate on fluoride removal through the anion exchange membrane, the performance of two types of ion exchange membrane (PC Cell and Neosepta) was compared. Experiments were carried out with synthetic solutions containing $0.0357 \mathrm{~mol} \mathrm{~L}^{-1}$ of $\mathrm{NaHCO}_{3}$ doped with $15 \mathrm{mg} \mathrm{L}^{-1}$ of fluoride. Sodium hydrogenocarbonate was replaced by sodium chloride or sodium
\end{abstract}

Ilhem Ben Salah Sayadi

Ilhem_bensalah@yahoo.fr

Soumaya Gmar

Soumaya.gmar@ymail.com

Nawel Helali

helalinawe177@yahoo.fr

Mohamed Tlili

Mohamed.tlili@certe.rnrt.tn

Mohamed Ben Amor

Mohamed.benamor@certe.rnrt.tn

1 Laboratory of Natural Water Treatment, Center of Researches and Water Technologies, P.B 273, 8020 Soliman, Tunisia 
sulphate at different values of molar ratio in order to maintain the initial ionic strength of the solution constant at $0.0357 \mathrm{~mol} \mathrm{~L}^{-1}$. It was shown that fluoride removal was influenced by chloride ions but not by sulphate ones.

Keywords Electrodialysis - Tap water $\cdot$ Fluoride removal $\cdot$ Specific power consumption $\cdot$ Salinity

\section{Introduction}

Located in a semi-arid zone, Tunisia has limited water resources (Burghard 2013). The scarcity of good water quality, in particular at the south regions, requires brackish water desalination to supply these regions with potable water. In addition to their high salinity, these waters contain high levels of fluoride (Mnif et al. 2010). Fluoride ions are necessary and beneficial for the human health at low concentration in drinking water. However, at high concentration, water becomes toxic and leads to serious problems such as dental and skeleton fluorosis and lesions of the endocrine glands, thyroid and liver (Fawell et al. 2006; Mohapatra et al. 2009). The optimum fluoride ion level in drinking water is considered to be between 0.5 and $1.0 \mathrm{mg} \mathrm{L}^{-1}$ (Fewtrell and Bartram 2001). According to the World Health Organization (WHO), the maximum acceptable concentration of fluoride is $1.5 \mathrm{mg} \mathrm{L}^{-1}$ (Fewtrell and Bartram 2008).

In the literature, many methods have been investigated to remove the excess of fluoride from water (Melidis 2015), such as adsorption (Loganathan et al. 2013), ion exchange (Kodama and Kabay 2001), chemical precipitation (Jiang et al. 2013), electrochemical techniques (Tezcan et al. 2013) and membrane processes like, nanofiltration (Chakrabortty et al. 2013), Donnan Dialysis (Boubakri et al. 2013), and electrodialysis (ED) (Menkouchi Sahli et al. 2007; Amor et al. 2001; Ben Sik Ali et al. 2010). Most of them suffer from one of the following drawbacks: high initial cost, lack of selectivity, low capacity and complicated or expensive regeneration. However, ED which is widely used for desalination of brackish water (Walha et al. 2007; Banasiak et al. 2007) presents many advantages: it is a simple process which has an average installatalion cost and low chemicals consumption (Zeni et al. 2005).

The interest in using ED processes to remove the excess of fluoride and other contaminants such as nitrate and borate from drinking water, has increased worldwide (Banasiak and Schafer 2009; Tahaikt et al. 2006; Menkouchi Sahli et al. 2008). It was demonstrated that ED is an efficient process for removing these contaminants from brackish waters while reducing their salinity. The removal of contaminants depends on several ED parameters, such us applied potential, flow rate, concentration of contaminant, nature of ionic exchange membrane used, etc. (Kabay et al. 2008; Zakia et al. 1998; Banasiak and Schafer 2009). Kabay et al. (2008) have found that the separation performance of fluoride from aqueous solution by electrodialysis increased when the initial concentration of fluoride in the feed solution increased. Percent removal of fluoride increased as the applied potential increased. However, the effect of feed flow rate was not apparent in the range of applied feed flow rate. Separation of fluoride was influenced by chloride but not by sulphate ions. Ben Sik Ali et al. (2010) have shown that fluoride removal rate increased when the flow rate decreased. They suggested that for low flow rate, ions stay longer time in the dilute compartments and can be transferred from one compartment to another. The type of anionic exchange membrane plays an important role in fluoride removal and some membranes were more selective to fluoride compared to others (Ergun et al. 2008). Ergun et al. (2008) have shown that the SB-6407 membrane was more efficient than the ACM Neosepta and the poly(2-chloroaniline) membranes for fluoride 
removal. It was also shown that the presence of co-existing anions in brackish water have an important role during the ED defluoridation process (Kabay et al. 2008; Ergun et al. 2008). Ergun et al. (2008) have shown that the reducing effect of sulphate ions on the transport of fluoride was higher than that of chloride ions. This was explained by considering interaction of both chloride and sulphate ions with the ionic group in the membrane and activity coefficient of fluoride in the presence of mono- and bi-valent ion set.

In this study, samples were collected from taps of 13 monitoring sites in southern Tunisia. Physicochemical analyses were made on collected samples in order to control their compositions. Knowing the high levels of fluoride in the underground waters of the mining area providing the drinking water, the aim of this work was to remove fluoride excess from tap water using ED technique. The effect of chloride and sulphate ions on fluoride removal was studied using two types of ions exchange membrane (PCCell and Neosepta).

\section{Materials and Methods}

\subsection{Natural Water Samples}

Thirteen samples were collected in February 2014 by the Regional Service of Environmental Health from taps at 13 monitoring sites in southern Tunisia. These waters had underground origin. The physicochemical characteristics of the two samples having the highest fluoride levels are given in Table 2. The two tap water samples were used to achieve electrodialysis treatment.

\subsection{Work Solutions}

Tested solutions used to study the effect of chloride and sulphate on fluoride removal through the anion exchange membrane were synthetic solutions containing $0.0357 \mathrm{~mol} \mathrm{~L}^{-1}$ of $\mathrm{NaHCO}_{3}$ doped with $15 \mathrm{mg} \mathrm{L}^{-1}$ of fluoride. Sodium hydrogenocarbonate was replaced by sodium chloride or sodium sulphate at different values of molar ratio in order to maintain the initial ionic strength of the solution constant. The rinsing electrode solution was $0.1 \mathrm{M} \mathrm{Na}_{2} \mathrm{SO}_{4}$ in order to prevent generation of toxic gas. All reagents were from analytical grade purchased from Sigma-Aldrich.

\subsection{Electrodialysis Equipment and Membranes}

The ED setup consisted of a power DC, a concentrate reservoir, a dilute reservoir, a rinsing electrode reservoir and three centrifugal pumps (Heidolph D-93309) equipped each with a flowmeter $(\mathrm{PC} \mathrm{Cell} \mathrm{GmbH})$ and three valves to control the feed flow rate in the compartment of ED cell. Figure 1 shows a simplified scheme of ED setup working in batch recirculation mode.

The ED cell was a PC Cell ED 64-004 (Germany) used as a conventional ED unit with two compartments: the dilute and the concentrate compartment. ED cell was made by two polypropylene blocks supporting electrodes. One electrode was made of Pt/Ir-coated Ti stretched (anode) and the other of Ti stretched metal (cathode). The membranes and spacers were stacked between the two electrode-end blocks. The ED stack was formed by ten repeating sections called cell pairs. A cell pair consisted of the following:

- cation exchange membrane

- dilute flow spacer $(0.5 \mathrm{~mm})$ 
Fig. 1 Scheme of the ED installation

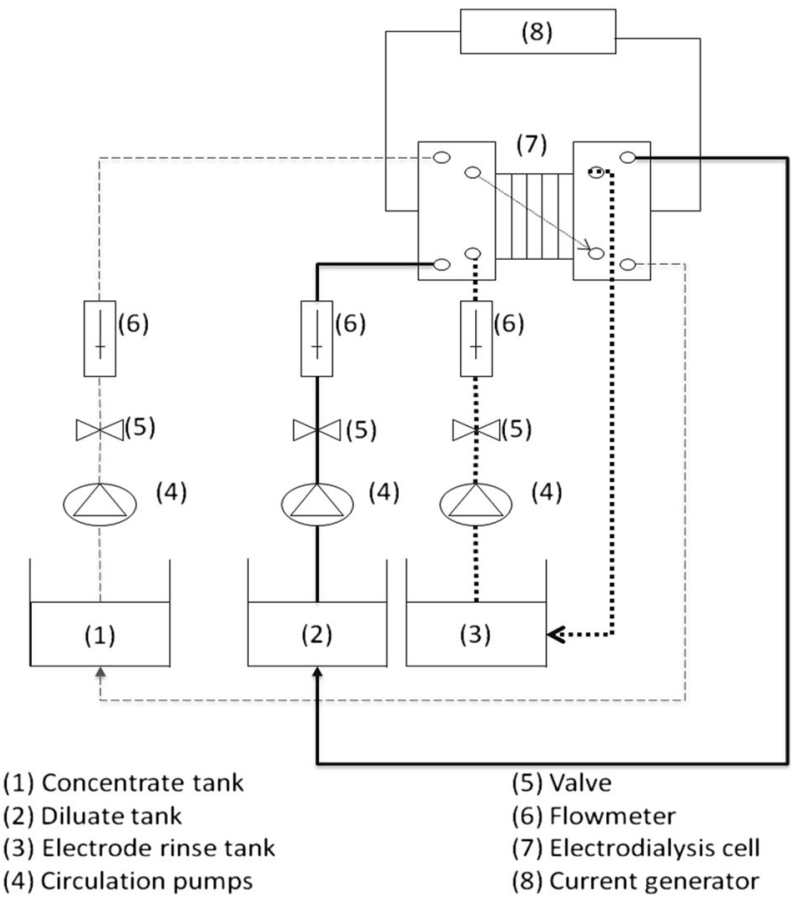

- $\quad$ anion exchange membrane

- concentrate flow spacer $(0.5 \mathrm{~mm})$

Spacers were made in plastic and were placed between the membranes to form the flow paths of the dilute and concentrate streams. The spacers were designed to minimize boundary layer effects and were arranged in the stack so that all the dilute and concentrate streams are manifold separately. For each membrane, the active surface area was $64 \mathrm{~cm}^{2}$. The flow channel width between two membranes was $0.5 \mathrm{~mm}$ determined by the thickness of intermembrane spacers. Two types of ions exchange membranes were used: PC Cell membranes (PC-SK and PC-SA were cation and anion exchange membranes, respectively) and Neosepta membranes (CMX and AMX were cation and anion exchange membranes, respectively). The main characteristics of used membranes are given in Table 1. The stack was equipped with three separate external plastic reservoirs: The first served to concentrate solution, the second to dilute solution and the third to rinse electrode solution. The fluid circulation was achieved using three pumps equipped with flowmeters. Experiments were performed in batch recirculation mode at ambient temperature.

\subsection{Experimental Procedure}

During all experiments, the volume of dilute, concentrate and rinsing electrode solutions was $1 \mathrm{~L}$ each. $0.1 \mathrm{M} \mathrm{Na}_{2} \mathrm{SO}_{4}$ was used as electrode rinse solution circulating in electrode compartment, in order to prevent generation of toxic gas. The flowrate of electrode rinse solution was fixed at $100 \mathrm{~L} \mathrm{~h}^{-1}$ for all experiments. However, the flowrates of other solutions (dilute and concentrate) were only fixed at the beginning of experiment in order to detect any 
Table 1 Characteristics of cation and anion exchange membranes

\begin{tabular}{llllll}
\hline Membrane & $\begin{array}{l}\text { Thickness } \\
(\mu \mathrm{m})\end{array}$ & $\begin{array}{l}\text { Ion exchange capacity } \\
\left(\mathrm{meq} \mathrm{g}^{-1}\right)\end{array}$ & $\begin{array}{l}\text { Chemical } \\
\text { stability }(\mathrm{pH})\end{array}$ & Permselectivity & $\begin{array}{l}\text { Membrane resistance } \\
\left(\Omega \mathrm{cm}^{2}\right)\end{array}$ \\
\hline PC- SK & 130 & $\approx 1$ & $0-11$ & 0.96 & $0.75-3$ \\
PC-SA & $90-130$ & $\approx 1.5$ & $0-9$ & 0.93 & $1-1.5$ \\
CMX & $170-190$ & $1.5-1.8$ & $0-12$ & 0.98 & $2.5-3.5$ \\
AMX & $160-180$ & $1.4-1.7$ & $0-12$ & 0.98 & $2.5-3.5$ \\
\hline
\end{tabular}

precipitation formation (Ben Salah Sayadi et al. 2013). Before the onset of the desalination test, the same solution was introduced in dilute and concentrate compartments. The experiment started at time of the potential application. Conductivity was recorded in time. It was measured using a conductivity meter (consort D 292), which was calibrated with commonly used standard $\mathrm{KCl} 0.01 \mathrm{M}$ and $0.1 \mathrm{M}$ solutions having a conductivity of 1.4 and $12.67 \mathrm{mS} \mathrm{cm}^{-1}$, respectively, at $298 \mathrm{~K}$ with a cell constant of $0.5 \mathrm{~cm}^{-1}$. Dilute and concentrate were circulated through the ED cell until the desired product conductivity was achieved in the dilute $\left.(0.5 \mathrm{mS} \mathrm{cm})^{-1}\right)$. Samples were taken periodically from dilute and concentrate compartments for analysis. After every experiment, ED cell was disassembled in order to observe the membrane states, assembled and cleaned with circulation of $0.1 \mathrm{M} \mathrm{HCl}$ solution for $15 \mathrm{~min}$ in order to remove any deposits followed by circulation of distilled water.

\subsection{Analytical Methods}

Fluoride concentration was determined using ion selective electrode (I.S.E 6.0502.150 fluoride ion electrode) in conjunction with a standard reference electrode connected to a Metrohm 781 $\mathrm{pH} /$ Ion-meter. To avoid possible interference resulting from changes in solution $\mathrm{pH}$ and conductivity, a total ionic strength adjustment buffer (TISAB) solution was used. It contained $58 \mathrm{~g}$ of $\mathrm{NaCl}$ and $57 \mathrm{~mL}$ of glacial acetic acid. The fluoride samples and the fluoride standard were diluted by addition of TISAB solution with a molar ratio of $1: 1$.

$\mathrm{Na}^{+}$and $\mathrm{K}^{+}$were analyzed by atomic emission spectroscopy using a "Sherwood 410 " spectrophotometer. $\mathrm{Ca}^{2+}$ and $\mathrm{Mg}^{2+}$ amounts were determined using a conventional colorimetric ethylene diamine tetraacetique (EDTA) titration. $\mathrm{HCO}_{3}{ }^{-}$was determined using a conventional colorimetric sulphuric acid $\left(\mathrm{H}_{2} \mathrm{SO}_{4}\right)$ titration. Nitrate and phosphate concentrations were measured by UV and visible spectrophotometric method, respectively. Chloride analysis was measured by potentiometric titration using an automatic titrator (metrohm 809). Sulphate concentration was determined by gravimetric analysis using $\mathrm{BaCl}_{2}$ in acidified medium. $\mathrm{pH}-$ meter (consort D 291) was used for measuring pH of solutions.

\subsection{Removal Rate of Fluoride Ions $\left(\mathrm{R}_{\mathrm{F}}{ }^{-} \%\right)$}

Removal rate of fluoride $\left(\mathrm{R}_{\mathrm{F}}{ }^{-} \%\right)$ by ED technique was calculated for all experiments by the following equation:

$$
\mathrm{R}_{\mathrm{F}^{-}}(\%)=100\left[1-\left(\frac{\mathrm{C}_{\mathrm{t}}}{\mathrm{C}_{0}}\right)\right]
$$


where $\mathrm{C}_{\mathrm{t}}\left(\mathrm{mg} \mathrm{L}^{-1}\right)$ is the fluoride concentration in dilute compartment, and $\mathrm{C}_{0}\left(\mathrm{mg} \mathrm{L}^{-1}\right)$ is the initial concentration of fluoride in the feed phase.

\subsection{Demineralization Rate (DR \%)}

The demineralization rate (DR \%) was calculated by the following equation:

$$
\operatorname{DR}(\%)=100\left[1-\left(\frac{S_{t}}{S_{0}}\right)\right]
$$

where $\mathrm{S}_{\mathrm{t}}\left(\mathrm{mg} \mathrm{L}^{-1}\right)$ is the salinity in the dilute compartment, and $\mathrm{S}_{0}\left(\mathrm{mg} \mathrm{L}^{-1}\right)$ is the initial salinity in the feed phase.

\subsection{Specific Power Consumption (SPC)}

Specific power consumption (SPC) can be described as the energy needed to treat a unit volume of solution. SPC was calculated using the following equation (Kabay et al. 2008):

$$
\mathrm{SPC}=\frac{\mathrm{E} \int_{0}^{\mathrm{t}} \mathrm{I}(\mathrm{t}) \mathrm{dt}}{\mathrm{V}_{\mathrm{D}}}
$$

where $\mathrm{E}$ is the applied potential, $\mathrm{I}$ is the current, $\mathrm{V}_{\mathrm{D}}$ is the dilute stream, and $\mathrm{t}$ is the time.

\section{Results and Discussion}

\subsection{Physicochemical Analysis of Tap Water}

Several samples of tap water distributed for human consumption, in south of Tunisia, were collected for physicochemical analysis. The salinity of these samples varied between 800 and $2200 \mathrm{mg} \mathrm{L}^{-1}$. The fluoride concentration varied between 0.8 and $4 \mathrm{mg} \mathrm{L}^{-1}$. In this study, only physicochemical characteristics of two samples of tap waters containing high concentration of fluoride and rich in sulphate and chloride ions are presented in Table 2.

Table 2 shows that fluoride concentration largely exceeds $1.5 \mathrm{mg} \mathrm{L}^{-1}$, value recommended by the World Health Organization for the two samples. The recommended values of $400 \mathrm{mg} \mathrm{L}^{-1}$ for sulphate and $45 \mathrm{mg} \mathrm{L}^{-1}$ for nitrate are also exceeded for the two samples. However, for the chloride, the recommended value of $250 \mathrm{mg} \mathrm{L}^{-1}$ was exceeded only for sample 2 .

\subsection{Treatment of Tap Water Samples by ED}

Applied potential (E), flowrate (Q) and concentration of salt (C) were optimized in a recent study using $2^{3}$ full factorial designs, for desalination of brackish water. This method of optimization could satisfy high demineralization rate with low energy consumption. The optimal conditions for desalination of brackish water were established at applied potential (E) $12 \mathrm{~V}$, flowrate (Q) $90 \mathrm{~L} \mathrm{~h}^{-1}$ and $C=1 \mathrm{~g} \mathrm{~L}^{-1}$. Then, conditions of applied potential $(E=$ $12 \mathrm{~V})$ and flowrate $\left(Q=90 \mathrm{~L} \mathrm{~h}^{-1}\right)$ were applied to desalinate the two samples with Total 
Table 2 Physicochemical characteristics of water samples

\begin{tabular}{lll}
\hline & Sample 1 & Sample 2 \\
\hline Conductivity $\left(\mathrm{mS} \mathrm{cm}^{-1}\right)$ & 1.90 & 3.16 \\
$\mathrm{pH}$ & 7.17 & 7.41 \\
$\mathrm{TDS}\left(\mathrm{mg} \mathrm{L}^{-1}\right)$ & 1200 & 2000 \\
$\mathrm{Cl}^{-}\left(\mathrm{mg} \mathrm{L}^{-1}\right)$ & 149 & 305.5 \\
$\mathrm{HCO}_{3}^{-}\left(\mathrm{mg} \mathrm{L}^{-1}\right)$ & 119.56 & 111 \\
$\mathrm{SO}_{4}{ }^{2-}\left(\mathrm{mg} \mathrm{L}^{-1}\right)$ & 467 & 889 \\
$\mathrm{~F}^{-}\left(\mathrm{mg} \mathrm{L}^{-1}\right)$ & 2.65 & 3.94 \\
$\mathrm{NO}_{3}^{-}\left(\mathrm{mg} \mathrm{L}^{-1}\right)$ & 54.54 & 55.5 \\
$\mathrm{PO}_{4}{ }^{3-}\left(\mathrm{mg} \mathrm{L}^{-1}\right)$ & 3.63 & 4 \\
$\mathrm{~K}^{+}\left(\mathrm{mg} \mathrm{L}^{-1}\right)$ & 4.21 & 7.345 \\
$\mathrm{Na}^{+}\left(\mathrm{mg} \mathrm{L}^{-1}\right)$ & 136.5 & 322 \\
$\mathrm{Ca}^{2+}\left(\mathrm{mg} \mathrm{L}^{-1}\right)$ & 138.5 & 179.5 \\
$\mathrm{Mg}^{2+}\left(\mathrm{mg} \mathrm{L}^{-1}\right)$ & 67.50 & 103.5 \\
\hline
\end{tabular}

Dissolved Salts (TDS) of 1200 and $2000 \mathrm{mg} \mathrm{L}^{-1}$, respectively. The physicochemical characteristics of treated waters are given in Table 3. As shown in Fig. 2 which describes the polarization curve of the solution, for the applied potential of $12 \mathrm{~V}$, the value of limit current density was not reached. $\mathrm{pH}$ variation due to the reaction of water dissociation into $\mathrm{H}_{3} \mathrm{O}^{+}$and $\mathrm{OH}^{-}$is then avoided and this limits the probability of fouling and/or scaling formation.

Defluoridation of tap water was achieved with fluoride concentration lower than the maximum recommended by WHO. Ninety-two percent of fluoride removal rate was obtained after 21 and $30 \mathrm{~min}$ of ED application, respectively for samples 1 and 2. Moreover, the concentration of different species in the treated water was lower than the amounts recommended by WHO for drinking water. The salinity around $400 \mathrm{mg} \mathrm{L}^{-1}$ was obtained after $21 \mathrm{~min}$ of ED application with $\mathrm{SPC}=2.52 \mathrm{Wh} \mathrm{L}^{-1}$ for sample 1 and $30 \mathrm{~min}$ with $3.48 \mathrm{Wh} \mathrm{L}^{-1}$ for sample 2. This difference was related to the initial salt concentration of samples. The increase of salt concentration enhances an

Table 3 Physicochemical characteristics of treated water at $E=12 \mathrm{~V}$ and $Q=90 \mathrm{~L} \mathrm{~h}^{-1}$ using PCCell membranes

\begin{tabular}{llll}
\hline & Sample 1 & Sample 2 & Recommended values by WHO \\
\hline Conductivity $\left(\mathrm{mS} \mathrm{cm}^{-1}\right)$ & 0.5 & 0,5 & 0.5 \\
$\mathrm{pH}$ & 6.95 & 7.17 & $6.5-8.5$ \\
$\mathrm{TDS}\left(\mathrm{mg} \mathrm{L}^{-1}\right)$ & 390 & 390 & 500 \\
$\mathrm{Cl}^{-}\left(\mathrm{mg} \mathrm{L}^{-1}\right)$ & 78 & 81.65 & 250 \\
$\mathrm{HCO}_{3}^{-}\left(\mathrm{mg} \mathrm{L}^{-1}\right)$ & 0 & 9.76 & - \\
$\mathrm{SO}_{4}{ }^{-}\left(\mathrm{mg} \mathrm{L}^{-1}\right)$ & 158.5 & 164.5 & 400 \\
$\mathrm{~F}^{-}\left(\mathrm{mg} \mathrm{L}^{-1}\right)$ & 0.212 & 0.283 & 1.5 \\
$\mathrm{NO}_{3}^{-}\left(\mathrm{mg} \mathrm{L}^{-1}\right)$ & 0.58 & 0.55 & 50 \\
$\mathrm{~K}^{+}\left(\mathrm{mg} \mathrm{L}^{-1}\right)$ & 2 & 5 & 12 \\
$\mathrm{Na}^{+}\left(\mathrm{mg} \mathrm{L}^{-1}\right)$ & 58.5 & 74 & 250 \\
$\mathrm{Ca}^{2+}\left(\mathrm{mg} \mathrm{L}^{-1}\right)$ & 16.5 & 7.60 & - \\
$\mathrm{Mg}^{2+}\left(\mathrm{mg} \mathrm{L}^{-1}\right)$ & 5.5 & 5.5 & - \\
\hline
\end{tabular}


increase in operation duration and SPC values. On the other hand, Fig. 3 shows that DR\% depends on initial salt concentration. A slight decrease is observed in the DR\% for water sample 2. An increase of the initial concentration leads to the decrease of $\mathrm{DR} \%$.

The desalination process could be stopped only after $5 \mathrm{~min}$ for a salinity value about $1000 \mathrm{mg} \mathrm{L}^{-1}$ and a fluoride concentration of $1 \mathrm{mg} \mathrm{L}^{-1}$ for sample 1 (Table 4). For sample 2, ED desalination could be stopped after $12 \mathrm{~min}$ for approximately the same salinity and a fluoride concentration of $0.55 \mathrm{mg} \mathrm{L}^{-1}$ (Table 4). To reach the desired conductivity value, $30 \mathrm{~min}$ were necessary as duration of ED treatment for sample 2 and only $21 \mathrm{~min}$ were required for sample 1 . This is due to the difference of initial salinities of the two samples (1310 $\mathrm{mg} \mathrm{L}^{-1}$ for sample 1 and $2179 \mathrm{mg} \mathrm{L}^{-1}$ for sample 2). At the end of desalination tests, the demineralized rate (DR) was about $75 \%$ for sample 1 and $77 \%$ for sample 2 (Fig. 3).

Figure 4 shows that the initial current intensity necessary for ion transfer is more important for sample 2. In fact, high initial concentration of salts requires high intensity of current for ion transfer. A significant reduction in the current intensity was observed for the two samples with curve slope of about 0.0098 and $0.0099 \mathrm{~A} \mathrm{~min}^{-1}$, respectively, for sample 1 and sample 2 . This can indicate that the two samples have nearly the same desalination progress.

\subsection{Effect of Chloride and Sulphate Ions on Fluoride Removal by ED}

Table 1 shows that analyzed waters are rich in sulphate and chloride ions. Then, to assess the effect of these two ions on fluoride removal by ED, two types of membranes (PC cell and Neosepta) were used. Experiments were, therefore, conducted with synthetic solutions containing $0.0357 \mathrm{~mol} \mathrm{~L}^{-1}$ of $\mathrm{NaHCO}_{3}$ doped with $15 \mathrm{mg} \mathrm{L}^{-1}$ of $\mathrm{F}^{-}$. Hydrogenocarbonate ions were replaced by chloride or sulphate at different values of molar ratio $\left(\mathrm{R}=\left[\mathrm{Cl}^{-}\right] /\left[\mathrm{HCO}_{3}{ }^{-}\right]\right.$and $\left.\mathrm{R}^{\prime}=\left[\mathrm{SO}_{4}{ }^{2-}\right] /\left[\mathrm{HCO}_{3}{ }^{-}\right]=0 ; 0.1 ; 0.25 ; 0.5 ; 0.75 ; 1\right)$. The ionic strength of the solutions was fixed at $0.0357 \mathrm{~mol} \mathrm{~L}^{-1}$ and maintained constant. Current applied and flowrate of dilute and concentrate compartments were fixed at $0.6 \mathrm{~A}$ and $40 \mathrm{~L} \mathrm{~h}^{-1}$, respectively, for all experiments. Under these conditions, the electrodialyser operates under the limiting current.

Figure 5 shows the competition between chloride and fluoride ions during their electromigration to the concentrate compartment. In fact, the fluoride removal rate $\left(\mathrm{R}_{\mathrm{F}^{-}}\right)$ reaches the lowest value $(\approx 84 \%)$ in $\mathrm{NaCl}$ solution $\left(\left[\mathrm{Cl}^{-}\right]=0.0357 \mathrm{M}\right)$ for a duration test of $30 \mathrm{~min}$. However, $\mathrm{R}_{\mathrm{F}^{-}}$increased for the low values of molar ratio $\left(\mathrm{R}=\left[\mathrm{Cl}^{-}\right] /\left[\mathrm{HCO}_{3}{ }^{-}\right]=0,0.1\right.$

Fig. 2 Polarization curve, $I=f(E)$

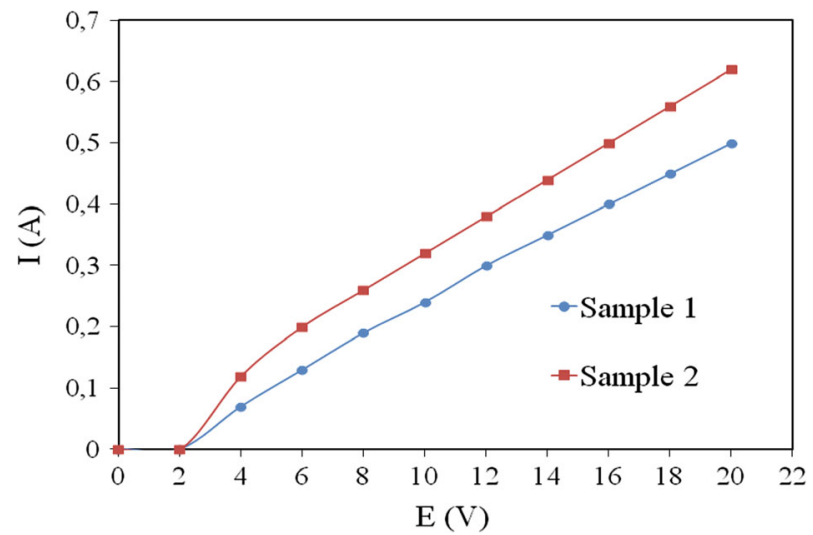


Fig. 3 Effect of initial salt concentration on $\mathrm{DR} \%$

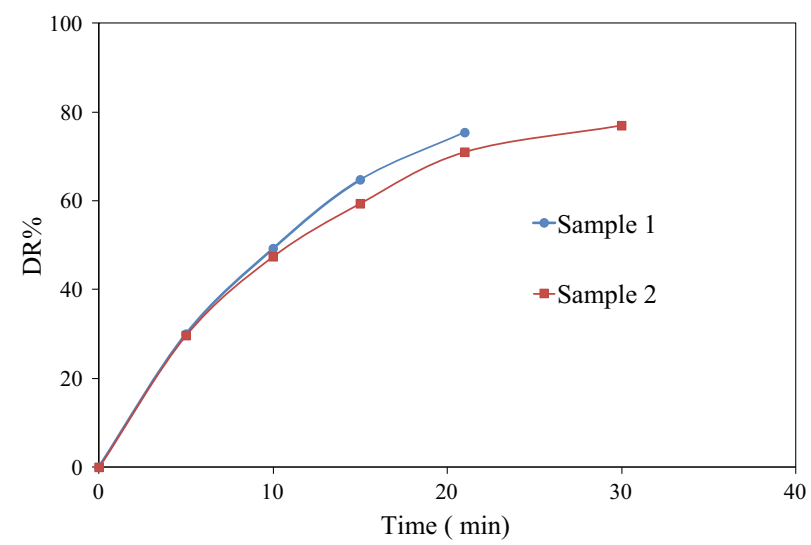

and 0.25 ) to reach $97 \%$ for low durations which last 24,25 and $26 \mathrm{~min}$, respectively. A decrease of $\mathrm{R}_{\mathrm{F}^{-}}$was observed for the ratio $0.5,0.75$ and 1.0 compared to the tests with low values of molar ratio. $\mathrm{R}_{\mathrm{F}^{-}}$of the corresponding tests $(0.5,0.75$ and 1.0$)$ reached the same value ( $97 \%$ ) but for the most important treatment durations (28, 29 and $35 \mathrm{~min}$, respectively). In fact, the hydrated radius (Table 5) plays an important role in the ion transfer; the ion which has small hydrated radius passes more easily through the ion-exchange membranes (Banasiak and Schafer 2009). The transit of fluoride ions is more difficult in $\mathrm{NaCl}$ solution than that in $\mathrm{NaHCO}_{3}$ solution $\left(\mathrm{R}=\left[\mathrm{Cl}^{-}\right] /\left[\mathrm{HCO}_{3}{ }^{-}\right]=0\right)$. This can explain the effect of chloride ion on the removal rate of fluoride. Similar results were obtained by Ben Sik Ali et al. (2010), Kabay et al. (2008) and Ergun et al. (2008).

Figure 6 shows that fluoride removal by ED was not influenced by sulphate ions. Fluoride removal is almost total for all values of molar ratio $\mathrm{R}^{\prime}\left(\mathrm{R}^{\prime}=\left[\mathrm{SO}_{4}{ }^{2-}\right] /\left[\mathrm{HCO}_{3}{ }^{-}\right]\right)$and for $\mathrm{Na}_{2} \mathrm{SO}_{4}$ solution $\left(\left[\mathrm{SO}_{4}{ }^{2-}\right]=0.0357 \mathrm{M}\right)$. The transfer of fluoride ions is more rapid than the transfer of sulphate ions. This is not in accordance with the results of Ben Sik Ali et al. (2010) and Ergun et al. (2008) which showed that the fluoride removal rate decreases in the presence of sulphate ions. The present results shown in Fig. 6 can be explained by the hydrated radius of ionic

Table 4 Variation of salinity, $\left[\mathrm{F}^{-}\right]$and SPC for samples 1 and 2

\begin{tabular}{|c|c|c|c|c|}
\hline Time (min) & Salinity $\left(\mathrm{mg} \mathrm{L}^{-1}\right)$ & {$\left[\mathrm{F}^{-}\right]\left(\mathrm{mg} \mathrm{L}^{-1}\right)$} & $\mathrm{SPC}\left(\mathrm{Wh} \mathrm{L}^{-1}\right)$ & $\mathrm{R}_{\mathrm{F}}^{-}(\%)$ \\
\hline \multicolumn{5}{|l|}{ Sample 1} \\
\hline 0 & 1310 & 2.65 & 0 & 0 \\
\hline 5 & 1034 & 1.05 & 0.8 & 60.37 \\
\hline 11 & 689.78 & 0.517 & 1.92 & 80.49 \\
\hline 21 & 325.78 & 0.212 & 252 & 92 \\
\hline \multicolumn{5}{|l|}{ Sample 2} \\
\hline 0 & 2179 & 3.94 & 0 & 0 \\
\hline 3 & 1724 & 1.88 & 0.4 & 52.28 \\
\hline 7 & 1379 & 1.24 & 0.84 & 68.52 \\
\hline 12 & 1034 & 0.55 & 2.28 & 86.04 \\
\hline 19 & 689.7 & 0.4 & 3 & 89.84 \\
\hline 30 & 325.78 & 0.283 & 3.48 & 92.81 \\
\hline
\end{tabular}


Fig. 4 Change of current versus time

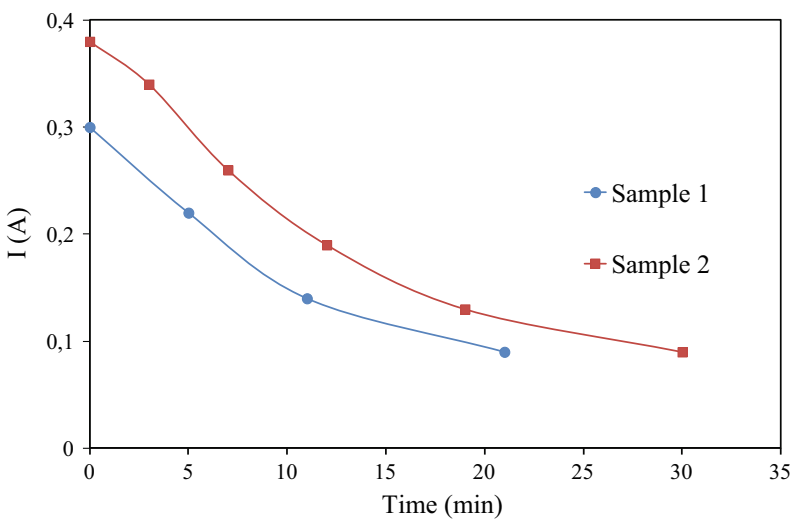

species. The hydrated radius of sulphate is greater than that of fluoride (Table 5). Then, the fluoride ions transfer more easily than the sulphate ones.

Figure 7 shows that fluoride removal is slightly improved for molar ratio from 0 to 0.75 ( $\mathrm{R}$ $=\left[\mathrm{Cl}^{-}\right] /\left[\mathrm{HCO}_{3}{ }^{-}\right]=0,0.1,0.25,0.5$ and 0.75$)$ compared to $\mathrm{NaCl}$ solution and $\mathrm{R}=1$ solution. We remind that ED treatment was stopped when the conductivity of the produced solution reached the value of $0.5 \mathrm{mS} \mathrm{cm}{ }^{-1}$. $\mathrm{R}_{\mathrm{F}^{-}}$passed from $95 \%$ for $\mathrm{R}=1$ solution to approximately $97 \%$ for solutions with the lowest molar ratio but for the most important treatment durations. For a same ED treatment duration (e.g., $t=17 \mathrm{~min}$ ), $\mathrm{R}_{\mathrm{F}^{-}}$passed from 73 to $86 \%$ for $R=0.75$ and to $92 \%$ for $R=0$. This clearly shows that, as during the tests using Neosepta membranes, the presence of chloride ions at high concentrations disturbs the fluoride transit.

Figure 8 shows that, similarly to the tests using Neosepta membranes, the presence of sulphate ions has no effect on fluoride removal. The ion size has also the determinant role on the transit order: the larger the ion, the more its transport through the membrane is hindered (Table 5). The removal rate of fluoride is slightly decreased for all solutions $\left(\mathrm{R}^{\prime}=\left[\mathrm{SO}_{4}{ }^{2-}\right] /\right.$ $\left[\mathrm{HCO}_{3}{ }^{-}\right]=0,0.1,0.5,0.75$ and 1) compared to $\mathrm{Na}_{2} \mathrm{SO}_{4}$ solution. Then, the fluoride transited more easily in the solution which contained only sulphate ions than in the solution which contained only hydrogenocarbonate ones. This behavior is not observed during tests using Neosepta membranes in the same conditions.

Fig. 5 Effect of chloride on fluoride removal by ED using Neosepta membranes

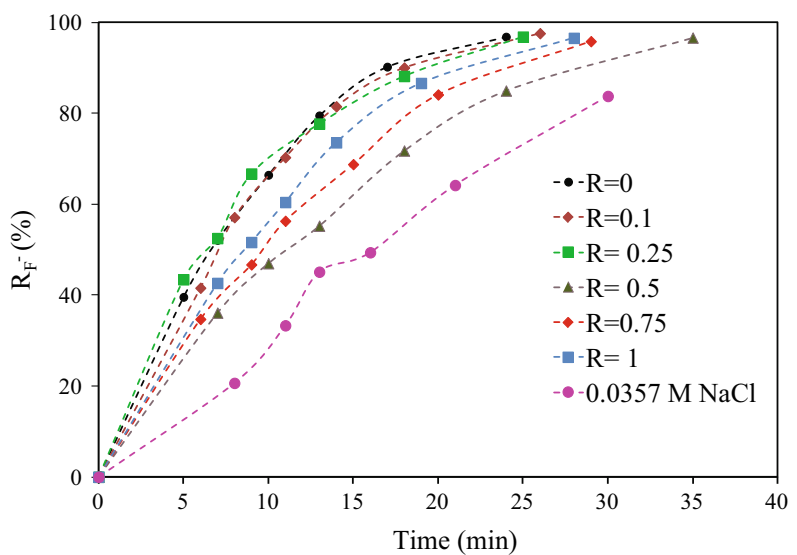


Table 5 Hydrated radius of ions (Kabay et al. 2008)

\begin{tabular}{ll}
\hline Hydrated radius $\left(\mathrm{A}^{\circ}\right)$ & Ionic species \\
\hline 3.32 & Chloride \\
3.52 & Fluoride \\
3.79 & Sulphate \\
\hline
\end{tabular}

The comparison between the performance of Neosepta and PC Cell membranes for the treatment of $\mathrm{NaCl}$ solutions shows that the use of PC Cell membranes allows reaching the desired conductivity value more rapidly $(20 \mathrm{~min})$ than the Neosepta membranes (30 $\mathrm{min})$. However, the best fluoride removal rate is obtained with the use of Neosepta membranes $\left(\mathrm{R}_{\mathrm{F}^{-}}=84 \%\right)$ against $82 \%$ obtained by PC Cell ones. For $R=0$ and 0.1 , AMX membrane seems to be more selective for fluoride ions than PC-SA membrane. $R_{F^{-}}$is evaluated at 97 and $98 \%$ during the use of AMX membrane, respectively, for $R=0$ and $R=0.1$ solutions. However, it reaches only 82 and $95 \%$ during the use of PC-SA membrane for the same solutions. For the highest values of molar ratio $\mathrm{R}\left(\mathrm{R}=\left[\mathrm{Cl}^{-}\right] /\left[\mathrm{HCO}_{3}{ }^{-}\right]=0.25,0.5\right.$ and 0.75$)$, the selectivity of AMX membrane for fluoride ions is stabilized $\left(\mathrm{R}_{\mathrm{F}^{-}} \approx 97 \%\right)$ and the selectivity of PC-SA is improved $\left(\mathrm{R}_{\mathrm{F}^{-}}=97 \%\right)$. Globally, AMX and PC-SA membranes have closed performances for solutions containing high concentration of chloride. In fact, ion transfer is a function of membrane structure and their characteristics. As seen in Table 1, AMX and PC-SA membranes have close values of ion exchange capacities $\left(1.4-1.7 \mathrm{meq} \mathrm{g}^{-1}\right.$ and $\approx 1.5 \mathrm{meq} \mathrm{g}^{-1}$, respectively). The thickness of membrane is also another factor which influences the ions transport. It may be expected that the transport of ion decreased with increasing membrane thickness (Ergun et al. 2008). The thickness of Neosepta membranes is higher than that of PC Cell ones. This can explain why the duration of ED treatment using PC Cell membranes for $\mathrm{NaCl}$ solution is lower than that using Neosepta ones, chloride ions having the smallest hydrated radius.

\section{Conclusions}

Tap waters in southern Tunisia (mining area) are naturally rich in fluoride and contain high concentrations of sulphate and chloride ions. The concentration of fluoride largely exceeded

Fig. 6 Effect of sulphate on fluoride removal by ED using Neosepta membranes

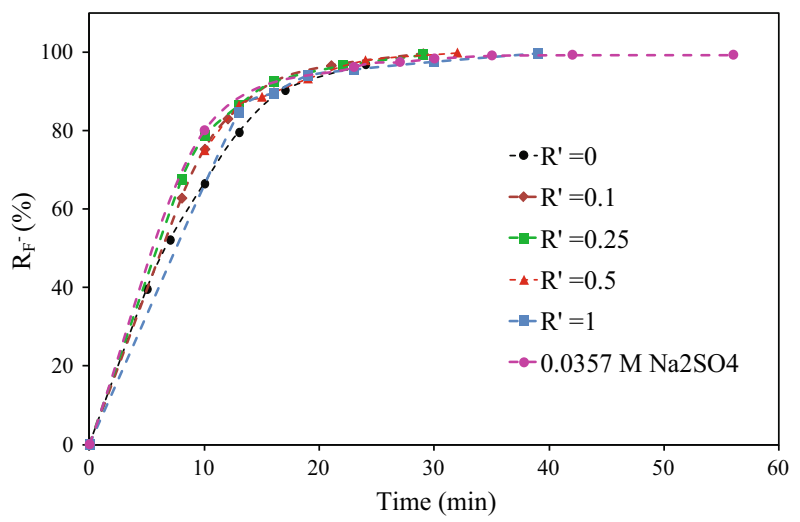


Fig. 7 Effect of chloride on fluoride removal by ED using PC Cell membranes

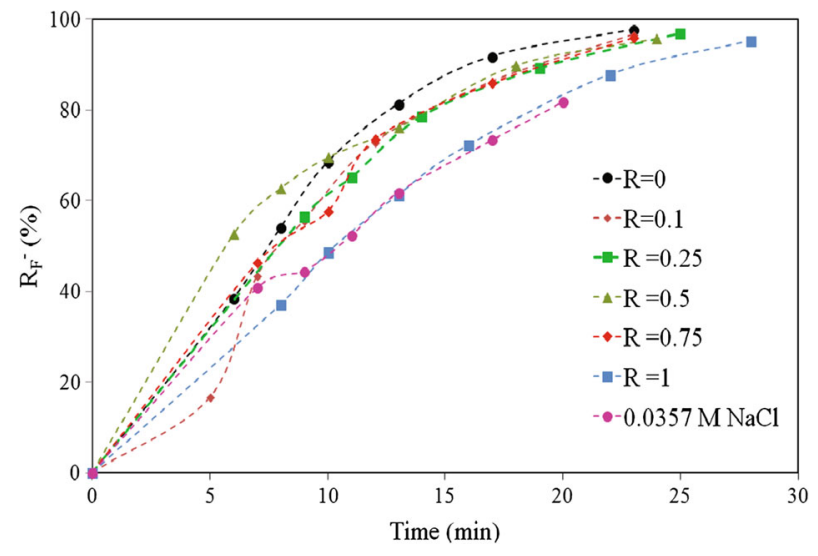

the value recommended by WHO and it varied between 0.8 and $4 \mathrm{mg} \mathrm{L}^{-1}$. It was shown that ED is an efficient method for removal of fluoride excess from water according to desalination tests performed on the two samples, characterized by the highest fluoride levels. Fluoride ions were reduced from 2.650 to $0.212 \mathrm{mg} \mathrm{L}^{-1}$, corresponding to a fluoride removal of $92 \%$ for the first sample, and from 3.940 to $0.283 \mathrm{mg} \mathrm{L}^{-1}$ (92.81\% removal) for the second one. The reached concentrations of fluoride are lower than the WHO standards as well as the concentrations of other ions for the produced water. The application of ED desalination allowed reducing the salinity to $1000 \mathrm{mg} \mathrm{L}^{-1}$ with fluoride concentration lower than $1 \mathrm{mg} \mathrm{L}^{-1}$ and in only 5 and $12 \mathrm{~min}$, respectively, for the two samples.

The effect of sulphate and chloride ions on fluoride removal by ED was studied using two types of ions exchange membranes (Neosepta and PC Cell). The results have shown that there is no competition between fluoride and sulphate ions using the Neosepta membranes as well as PC Cell ones. However, the competition between fluoride and chloride was proved using the two membranes. The transit of fluoride ions is more difficult in $\mathrm{NaCl}$ solution than that in $\mathrm{NaHCO}_{3}$ solution and solutions containing high chloride concentrations. This competition was explained by the hydrated radius of ions: the ion which has little hydrated radius passes more easily through the ion-exchange membranes.

Fig. 8 Effect of sulphate on fluoride removal by ED using PC Cell membranes

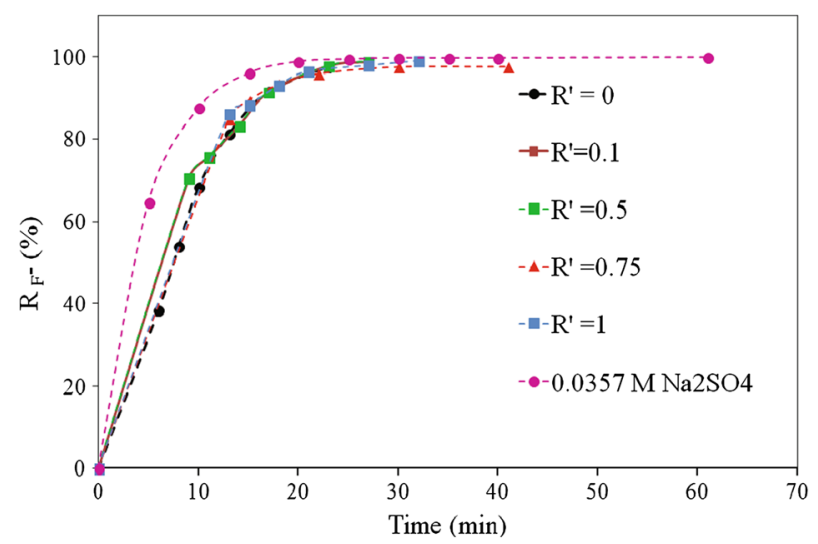


$C$ concentration, $D R(\%)$ demineralization rate, $E$ potential, $E D$ electrodialysis, $Q$ flow rate, $R_{F}^{-}(\%)$ removal rate of fluoride, SPC specific power consumption, TDS total dissolved salts, $T I S A B$ total ionic strength adjustment buffer, WHO World Health Organization

Acknowledgments An initial version of this paper has been presented at the International Conference on Integrated Management of Environment (http://www.icime.net), 25-28 September 2014, Hammamet, Tunisia.

\section{References}

Amor Z, Bariou B, Mameri N, Takey M, Nicolas S, Elmidaoui A (2001) Fluoride removal from brackish water by electrodialysis. Desalination 133:215-223

Banasiak LJ, Schafer AI (2009) Removal of boron, fluoride and nitrate by electrodialysis in the presence of organic matter. J Membr Sci 334:101-109

Banasiak LJ, Kruttschitt TW, Schafer AI (2007) Desalination using electrodialysis as a function of voltage and salt concentration. Desalination 205:38-46

Ben Salah Sayadi I, Ben Amor M, Sistat P, Tlili MM (2013) Brackish water desalination by electrodialysis: $\mathrm{CaCO}_{3}$ scaling monitoring during batch recirculation operation. Inter J Chem React Eng 11(1):1-9. doi:10. 1515/ijcre-2013-0082

Ben Sik Ali M, Hamrouni B, Dhahbi M (2010) Electrodialytic defluoridation of brackish water: effect of process parameters and water characteristics. Clean Soil Air Water 38(7):623-629. doi:10.1002/ clen.200900301

Boubakri A, Helali N, Tlili M, Ben Amor M (2013) Fluoride removal from diluted solutions by Donnan dialysis using factorial design. Korean J Chem Eng 10:1-6. doi:10.1007/s11814-013-0263-9

Burghard M (2013) Solar power plant technology and future perspective for water desalination in the Maghreb region. Conference, the 4th Maghreb conference on desalination and water treatment

Chakrabortty S, Roy M, Pal P (2013) Removal of fluoride from contaminated groundwater by cross flow nanofiltration: transport modeling and economic. Desalination 313:115-124

Ergun E, Tor A, Cengeloglu Y, Kocak I (2008) Electrodialytic removal of fluoride from water: effects of process parameters and accompanying anions. Sep Purif Technol 64:147-153

Fawell J, Bailey K, Chilton J, Dahi E, Fewtrell L, Magara Y (2006) Fluoride in drinking -water. World Health Organization, Geneva, pp 32-35

Fewtrell L, Bartram J (2008) WHO, guidelines for drinking water quality. Third edition incorporating the first and second addenda, vol 1, Geneva, p 37.

Fewtrell L, Bartram J (2001) Water quality: guidelines, standards and health

Jiang K, Zhan K, Yan Y, Du H (2013) A pilot-scale study of cryolite precipitation from high fluoride-containing wastewater in a reaction-separation integrated reactor. J Environ Sci 25(7):1331-1337

Kabay N, Arar O, Samatya S, Yuksel U, Yuksel M (2008) Separation of fluoride from aqueous solution by electrodialysis: effect of process parameters and other ionic species. J Hazard Mater 153:107-113

Kodama H, Kabay N (2001) Reactivity of inorganic anion exchange $\mathrm{BiPbO}_{2}\left(\mathrm{NO}_{3}\right)$ with fluoride ions in solution. Solid State Ionics 141(142):603-607

Loganathan P, Vigneswaran S, Kandasamy J, Naidu R (2013) Defluoridation of drinking water using adsorption processes. J Hazard Mater 248-249:1-19

Melidis P (2015) Fluoride removal from aluminium finishing wastewater by hydroxyapatite. Environ Process 2: 205-213

Menkouchi Sahli MA, Annouar S, TAhaikt M, Mountadar M, Soufiane A, Elmidaoui A (2007) Fluoride removal for underground brackish water by adsorption on the natural chitosan and by electrodialysis. Desalination 212:37-45

Menkouchi Sahli MA, Annouar S, Mountadar M, Soufiane A, Elmidaoui A (2008) Nitrate removal of brackish underground water by chemical adsorption and by electrodialysis. Desalination 227:327-333

Mnif A, Ben Sik Ali M, Hamrouni B (2010) Effect of some physical and chemical parameters on fluoride removal by nanofiltration. Ionics $16: 245-253$

Mohapatra M, Anand S, Mishra BK, Giles ED, Singh P (2009) Review of fluoride removal from drinking water. J Environ Manag 91:67-77

Tahaikt M, Achary I, Menkouchi Sahli MA, Amor Z, Takay M, Alami A, Boughriba A, Hafsi M, Elmidaoui A (2006) Defluoridation of Moroccan ground water by electrodialysis: continuous operation. Desalination 189: $215-220$ 
Tezcan U, Savas Koparal A, Bakir Ogutvern U (2013) Fluoride removal from water and waste water with a bach cylindrical electrode using electrocoagulation. Chem Eng J 223:110-115

Walha K, Ben Amar R, Firdaous L, Quemeneur F, Jaouen P (2007) Brackish groundwater treatment by nanofiltration, reverse osmosis and electrodialysis in Tunisia: performance and cost comparison. Desalination 207:95-106

Zakia A, Suad M, Mohamed T, Bernard B, Nabil M, Azzedine E (1998) Optimization of fluoride removal from brackish water by electrodialysis. Desalination 120:263-271

Zeni M, Riveros R, Melo K, Primieri R, Lorenzini S (2005) Study on fluoride reduction in artesian well-water from electrodialysis process. Desalination 185:241-244 